\title{
OHJAUKSEN ARVIOINTI TUO PÄÄTTÄJÄT JA OHJAUKSEN AMMATTILAISET SAMAAN KESKUSTELUUN
}

\begin{abstract}
OECD ja EU-komissio ovat viime vuosina tuoneet esiin, että mahdollisuus elinikäiseen ohjaukseen on välttämätön elinikäisen oppimisen toteutumiselle ja elämän eri siirtymävaiheiden läpikäymiselle. OECD:n ja EU-komission kannanotot sekä kansainväliset ja kotimaiset ohjauksen arviointihankkeet voivat tuoda päättäjät ja ohjausammattilaiset yhteiseen keskusteluun pohtimaan ura- ja elämänsuunnittelun muutoksia.
\end{abstract}

\section{JUSSI ONNISMAA}

$\mathrm{O}$ hjauksella on erityinen roolinsa, kun luodaan ihmisille mahdollisuuksia paikantaa työelämä ja urasuunnittelu oman elämänsä osaksi ja toisaalta paikantaa itsensä työelämässä. Ohjaus on viime kädessä myös poliittinen prosessi yksilöllisten ja yhteiskunnallisten tarpeiden sekä yksityisten ja julkisten identiteettien välillä. Yksilön työ- ja elämänuraa voi tarkastella yksilöllisen toiminnan, talouden ja sosiaalisten rakenteiden leikkauskohtana (Kurhila ym. 2002, Watts 1997, Young \& Collin 2001).

Ura- ja elämänsuunnittelun kysymykset ovat viime vuosina muuttuneet siinä määrin monimutkaisiksi, etteivät ohjausammattilaiset ja päättäjät enää tule toimeen ilman toistensa asiantuntemusta. Laajakantoisin kansainvälinen prosessi, jossa pyritään kehittämään ohjauksen käytäntöjä ja parantamaan päättäjien ja ohjausammattilaisten yhteistyötä, on Kanadassa tähän mennessä kahdesti järjestetty International symposium on career development and public policy. Prosessissa ovat mukana Suomen ja 16 muun maan lisäksi OECD, EU-komissio, ILO ja Maailmanpankki (Onnismaa 2002). Symposiumien seurantakokouksessa viime vuoden lopulla todettiin, että ohjauksen arviointi voi olla tehokas keino tuoda uraja elämänsuunnittelun kysymykset päättäjien asialistalle.

Sektoroituneen toimintakulttuurin muutosta lupaava kotimainen esimerkki oli Jyväskylän
Ohjauksen tulevaisuus 2002-2012 -seminaari viime vuoden lopussa. Seminaarissa eri sektorien päättäjät, hallinnon edustajat, tutkijat ja ohjausammattilaiset kävivät keskustelua ohjauksen ajankohtaisista kysymyksistä, ennen kaikkea kansainvälisistä ja kotimaisista ohjauksen arviointihankkeista.

\section{OECD JA EU OHJAUKSESTA}

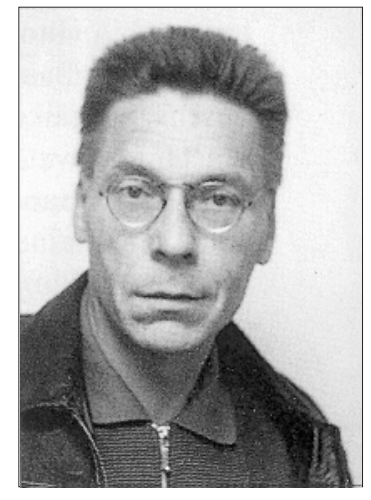

Jussi Onnismaa
OECD arvioi jäsenmaidensa

ohjauksen, neuvonnan ja tiedotuksen kansallista toimintapolitiikkaa. Hankkeessa ohjausta tarkastellaan ensimmäisen kerran elinikäisenä prosessina. Mukana on Suomi ja 13 muuta maata (OECD 2002).

Richard Sweet kertoi hankkeesta Jyväskylän ohjauksen tulevaisuusseminaarissa. Tulosten mukaan urasuunnittelun ohjausta kouluissa tulisi kehittää selvemmin osana elinikäistä oppimista, ja tavoite tulisi asettaa pitemmälle kuin seuraavalle kouluasteelle siirtymiseen. Ohjauksella tulisi olla koulutusorganisaatioissa selkeä identiteetti. Korkea-asteen ohjaus on monessa jäsenmaassa puutteellisesti hoidettu. Työhallinnon 
palveluja suunniteltaessa tulisi Sweetin mukaan kiinnittää nykyistä enemmän huomiota elinikäiseen oppimiseen. Työssä olevien aikuisten ohjauspalvelut koettiin arvioinnissa puutteellisiksi, ja myös väestön ikääntyminen tulisi ottaa huomioon ohjauspalvelujen kehittämisessä.

OECD:n arviointihankkeen tuloksia selvitti Myös Tony Watts Uuden Seelannin marraskuisessa Pushing the boundaries -ohjauskonferenssissa. Ohjauksen järjestelmä pyritään eri maissa suhteuttamaan elinikäisen oppimisen periaatteisiin ja kestävään työllisyyteen, mutta palvelut on ensisijaisesti suunnattu vain nuorille ja työttömille. Uratiedon saanti ei ole nykyisellään riittävää. Mikään maa ei ole onnistunut kehittämään elinikäisen ohjauksen kokonaisstrategiaa, mutta järjestelmän aineksia on paikoin havaittavissa.

Tiedotus, neuvonta- ja ohjausalalla toimivan henkilöstön ammatillisuutta tulisi Wattsin mukaan vahvistaa. On olemassa riski, että koulujen urasuunnittelu ja ohjaus kapenevat ja marginalisoituvat. Joissain maissa työmarkkinoille siirtyminen näyttää korostuvan liiaksikin, toisaalla taas opiskelijoiden lisääntyneet henkilökohtaiset ongelmat, joista ohjaajat kantavat kokonaisvastuuta, vievät liiaksi voimavaroja. Yleissivistävän ja korkea-asteen ohjauksessa keskitytään vain kurssija jatkokoulutusvalintoihin, mutta niiden vaikutuksia ammatilliseen suuntautumiseen tai työmarkkinoiden mahdollisuuksiin ei ohjauksessa ole tilaisuutta tarkastella. Tietoa nykyisistä tai tulevista työmarkkinoista ei ole riittävästi saatavilla, ja osa opiskelijoista jää vaille riittävää ammatillista uraohjausta.

Watts pahoitteli sitä, etteivät päättäjät vieläkään tunnu ymmärtävän ura- ja elämänsuunnittelun kysymyksiä päätellen siitä, miten kerkeästi budjetteja eri maissa leikataan. Watts ja OECD:n sihteeristön edustaja Richard Sweet ovat eri yhteyksissä korostaneet, että OECD:n rooli voi olla merkittävä lujitettaessa ohjauksen asemaa eri maissa.

OECD:n ohjauksen arvioinnin tuloksia hyödyntää myös EU-komissio Life Long Guidance komiteassaan sekä Maailmanpankki kehitysmaiden ohjausta selvittäessään.

Jyväskylän ohjauksen tulevaisuusseminaarissa John McCarthy EU-komissiosta toi esille "ohjauksen eurooppalaisen ulottuvuuden". Komission elinikäisen oppimisen valmisteluasiakirjassa korostetaan ohjausta Euroopan laajuisena ja toisaalta kansallisena sekä alu- eellisena kysymyksenä. Ohjauksen osa-alueina muistiossa mainitaan opintojen, urasuunnittelun, henkilökohtaisen ja ammatillisen kasvun ohjaus. EU-komissio painottaa riittävän ja laadukkaan ohjauksen saatavuutta kaikissa elämän vaiheissa. Komission tiedonannossa Eurooppalaisen elinikäisen oppimisen alueen toteuttaminen todetaan, että elinikäinen oppiminen vaatii nykyistä paljon laajempaa urasuunnittelua tukevan tiedon ja ohjauksen saatavuutta sekä aikuisille että nuorille muutosvaiheissa (McCarthy 2002; EU 2001).

Voiko OECD:n ja EU:n suosituksilla ja kannanotoilla olla käytännön vaikutuksia? Suomalaiset päättäjät ovat aiemmin kuunnelleet varsin herkällä korvalla koulutus- ja tiedepolitiikan kansainvälisiä suosituksia, vaikka alue virallisesti kuuluu kansallisen päätöksenteon piiriin. OECD tutki 1987 Suomen tiede- ja teknologiapolitiikkaa. Esitettiin, että perustettaisiin elin, joka vastaisi sektorin tiedepoliittisesta ohjauksesta. Niinpä Suomeen perustettiin Valtion tiede- ja teknologianeuvosto. OECD tutki suomalaista korkeakoulupolitiikkaa 1994 ja arvosteli yliopistojen evaluaation heikkoutta ja sattumanvaraisuutta. Seuraavana vuonna Suomeen perustettiin Korkeakoulujen arviointineuvosto. OECD:n opetusministerikokouksen 1996 teemana oli elinikäinen oppiminen. Suositeltiin, että jäsenmaat tekisivät strategiasuunnitelmansa elinikäisestä oppimisesta. Suomen strategia valmistui komiteanmietintönä seuraavana vuonna (Laukkanen \& Ollikainen 2001).

\section{KOTIMAISET OHJAUKSEN ARVIOINTIHANKKEET}

Ohjausta on viime vuosina arvioitu Suomessa laajasti eri oppilaitosasteilla ja työhallinnossa. Miksi eri alojen politiikkaa ja hallintoa arvioidaan enemmän kuin ennen? Uusikylän (1999) mukaan arvioinnin lisääntymisen taustalla voidaan nimetä ainakin seuraavia tekijöitä:

1) Tulosjohtamiskulttuuri ja päätösvallan hajauttaminen sekä normi- ja resurssiohjauksen korvaaminen informaatio-ohjauksella korostaa arviointitiedon merkitystä. Arviointien avulla voidaan myös välittää palautetta hallituksen politiikan toimeenpanosta ja vaikuttavuudesta.

2) OECD ja EU ovat kumpikin omalla tavallaan edistäneet arviointikulttuuria.

3) Hallinto ja päättäjät haluavat legitimoida tulevat tai jo tehdyt päätökset tutkimustiedon 
avulla. Tästä voi aiheutua paineita arvioijien puolueettomuudelle ja riippumattomuudelle.

4) Arviointitutkimuksen lisääntymisen taustalla voidaan lisäksi nähdä yleisiä jälkiteollisia kehityssuuntia kuten yhteiskuntatutkimuksen professionaalistuminen, politiikan ja hallinnon tieteellistyminen sekä asiantuntijavallan kasvu ylipäänsä.

Uusikylän mainitsemat tekijät ovat epäilemättä myös ohjauksen lisääntyneen arvioinnin taustalla, mutta ohjauksen kannalta ajankohtaisin kysymys lienee arviointien mahdollinen vaikutus eri osapuolten saamiseksi saman pöydän ääreen pohtimaan uusia ratkaisuja uusien ura- ja elämänsuunnittelun kysymysten edessä.

Opetushallitus arvioi opintojen ohjauksen tuloksellisuutta perusasteen ja toisen asteen koulutuksessa vuosina 2001-2002. Tarkasteltiin erityisesti siirtymävaiheita peruskoulusta toisen asteen koulutukseen ja toisen asteen koulutuksesta eteenpäin (Numminen ym. 2002). Hanke on sitoutunut opetushallituksen yleiseen arviointikehykseen, mikä voi olla ongelmallista ohjauksen poiketessa melko tavalla koulun muista sisällöistä. Tulokset ovat joka tapauksessa selkeät.

Voidaan sanoa, että koululainsäädäntö ei toteudu, kun joka viides yläasteen oppilas katsoo jääneensä vaille henkilökohtaista opinto-ohjausta. Liian vähäisin ohjausresurssein toimii arviointitulosten mukaan peruskouluista viidesosa, lukioista vajaa kolmasosa ja ammatillisista oppilaitoksista runsas kolmasosa. Peruskoulun uranvalinnan ohjaus ei ole ollut riittävää, kun puolet lukioon menneistä opiskelijoista sanoo valinneensa lukion vain harkinta-aikaa saadakseen, ja ammatillisen koulutuksen opiskelijoista vain 15 prosenttia ilmoittaa olevansa omalla alallaan. Epävarmoja valitsemastaan alasta on 30 prosenttia ja yli puolet katsoo, ettei ole omalla alallaan.

Korkeakoulujen arviointineuvosto arvioi yliopistojen ja ammattikorkeakoulujen opintojen ohjausta opiskelijan opintopolun toteutumisen ja järjestelmän toimivuuden kannalta. Arviointiryhmän mukaan opintojen ohjausjärjestelmää ei ole suunniteltu kokonaisuutena, eivätkä opiskelijat aina tiedä, mistä ohjausta on saatavissa. Henkilökohtaisten opintosuunnitelmien laadinta ja koko opiskeluajan kattava tutorointi lisäisivät opiskelun tavoitteellisuutta ja vastuun ottamista omasta oppimisesta (Moitus ym. 2001).
Yhteenvetona kotimaisista ohjauksen arviointituloksista voi sanoa, että riittävän ja ammattitaitoisen ohjauksen saatavuutta ei ole turvattu eri koulutusasteilla. Opiskelutaitojen ohjaus on koettu puutteelliseksi. Kaikilla koulutusasteilla ammatillisen suuntautumisen ohjaus on ohutta. Palautejärjestelmät ovat puutteellisia, ja kaikilla koulutusasteilla on pulaa koulutetuista ohjausalan ammattilaisista.

Aikuiskoulutuksessa ohjauksen resurssitilanne on vaikea. OECD (2003) on kiinnittänyt huomiota oma-aloitteisuutta ja itseohjautuvuutta suosivaan aikuiskoulutukseen ja suositellut neuvontaa ja ohjausta koulutuksen ulkopuolella olevien mukaan saamiseksi. Ohjauksellisuus suomalaisessa ammatillisessa aikuiskoulutuksessa on toteutunut pääasiassa oppimisen henkilökohtaistamiseen ja henkilökohtaisiin opiskeluohjelmiin liittyvinä käytäntöinä (AiHe 2002, Onnismaa 2003). Joensuun yliopiston toteuttama ja opetushallituksen tilaama aikuisten ohjauksen arviointi valmistuu tämän vuoden lopulla.

\section{OHJAUKSEN TALOUDELLINEN VAIKUTTAVUUS}

Uuden Seelannin Pushing the boundaries -ohjauskonferenssissa marraskuun lopussa pohdittiin ohjauksen taloudellista vaikuttavuutta. Derbyn yliopiston Centre for Guidance Studies 'in johtaja Deidre Hughes totesi, että nuorten ja aikuisten ohjauksen yksilö- yhteisö- ja yhteiskunnan tason taloudellisten vaikutusten osoittaminen on kaikille osapuolille haasteellinen tehtävä. Liian monet nuoret ja aikuiset tekevät uraa koskevia päätöksiä vailla riittävää tietoa työmahdollisuuksista ja omista mahdollisuuksistaan.

Vaikutusten nykyistä tarkempi selvittäminen perustuu panosten ja tuotosten tarkkaan määrittelyyn sekä ohjausammattilaisten ja taloustutkijoiden tiiviiseen yhteistyöhön. Paljon riippuu siitä, miten tuotettava sekä olemassa oleva mutta hajanainen tutkimustieto paikannetaan ja palautetaan relevantiksi ja käsitettäväksi tiedoksi, so. vastattaviksi kysymyksiksi. Tuloksia on voitava soveltaa käytäntöön ja omaa toimintaa on arvioitava jatkuvasti (Mayston 2002, Bysshe ym. 2002).

Taulukossa 1 on kuvattu aikuisten tiedotusneuvonta- ja ohjauspalveluiden (TNO) taloudellisten vaikutusten arviointikehys. Erityistä huomiota kiinnitetään ohjauksen asiakkaiden tilanteiden pitkäaikaiseen seurantaan. Englantilaiset 


\section{Tiedotuksen, neuvonnan ja ohjauksen (TNO) kontekstuaalisia tekijöitä ja määritteitä}

Yksilö: mm. ikä, sukupuoli, etninen ryhmä, koulutus, työmarkkina-asema, elämänhallinta, ammatillinen kypsyys, tiedon ja ohjauksen tarve.

Henkilökohtainen tilanne: mm. kotitilanne, paikalliset työmarkkinat, paikkakunnan sijainti, TNO-palveluiden saatavuus.

Instituutioiden tilanne: työnantajien vaatimukset, etuuksien saamisen ehdot, oppilaitosten toimintatapa.

\section{Tiedotus, neuvonta ja ohjaus (TNO)}

$\mathrm{Mm}$. interventioiden ja tuen kesto ja intensiivisyys; saatavan tuen tyyppi kuten erillinen/muuhun palveluun liittyvä tukimuoto.

Yksittäiset TNO-palvelut voivat olla työhön sijoittumista, oppimista, asiakkaan etujen ajamista (advocacy) jne.

\section{Välittömät tulokset}

Lisääntyneet tiedot ja taidot seuraavilla alueilla: Päätöksentekotaidot, tietoisuus mahdollisuuksista, urataidot (career management) kuten onnistuneiden siirtymävaiheiden toteutus, omien suunnitelmien edistäminen.

Asennemuutokset: Optimismin ja päättäväisyyden lisääntyminen, elämänhallinta, stressin/ahdistuksen väheneminen.

Työ- ja/tai oppimismotivaatio.

\section{Keskipitkän aikavälin tulokset}

Haku: Parantuneet oppimis- ja työmahdollisuuksien hakustrategiat, haun intensiivisyys ja kesto, yksilön selvittämät etenemistavat ja niillä eteneminen.

Päätöksenteko: Lisääntynyt toimintakyky, suunnitelmallisuus, pettymysten sieto.

\section{Pitkän aikavälin tulokset (yksilö)}

Koulutus: Mahdollisuuksiin tarttuminen, opiskelumenestys, koulutuksen soveltuvuus ammatillisten valintojen kannalta, opiskelun kesto.

Vaikutukset työvoiman tarjontaan (labour supply effects): Palkkataso, työmarkkinoille siirtyminen ja niiltä poistuminen.

Vaikutukset työhön: Parantunut työllisyystilanne, urataidot (career management) ja uralla eteneminen, työpanoksen ja tuottavuuden paraneminen.

\section{Pitkän aikavälin tulokset (talous)}

Työnantajat: Parantunut tuottavuus, vähentyneet työvoiman rekrytointi- ja vaihtuvuuskulut, lisääntynyt joustavuus ja valmius ottaa käyttöön uusia tuotannon tapoja.

Oppilaitokset/oppimismahdollisuuksien tarjoajat: Parantunut opiskelijoiden rekrytointi, keskeyttämisten vähentyminen, parantuneet oppimistulokset, oppilaitosten parantuneet tulot, valmiudet suunnitella ja järjestää oppimista tarpeita vastaavaksi.

Talous: BKT:n kasvu, työvoiman taitojen parantuminen, työttömyyden väheneminen, tulonsiirtojen säästöt. 
ohjausammattilaiset kokivat Hughesin mukaan arviointimallin tukevan käytännön työtään, ja aikuiset ohjauksen asiakkaat vastasivat mielellään ohjauskokemuksia ja sen vaikutuksia koskeviin kysymyksin.

Ohjausammattilaisen näkökulmasta taulukon kuvaus ohjauksen taloudellisista vaikutuksista voi vaikuttaa ohjauksen ominaispiirteitä tavoittamattomalta. Ohjausammattilaisten tulisi kuitenkin asiantuntijoina osallistua ohjauksen toivottavien tulosten ja arviointikriteerien määrittelyyn sen sijaan, että he odottelisivat muiden tahojen määrittelevän ne heidän puolestaan. Päättäjät odottavat joka tapauksessa konkreettisia tuloksia myönnettyjen resurssien vastapainoksi.

Deidre Hughesin mukaan Englannissa on havaittu, etteivät ohjausammattilaiset osaa riittävän selkeästi perustella päättäjille ohjauksesta saatavaa hyötyä, joka ei muin keinoin olisi saavutettavissa. Kun pyritään ohjausammattilaisten ja päättäjien dialogiin, perinteisesti toisistaan irrallisten päätöksenteon alueiden yhteen liittäminen voi olla hyödyllistä ohjauksen eri osapuolille.

Ohjausalan kustannus-hyöty-keskustelussa on jäsennetty riittämättömästi paitsi saatuja tuloksia, myös sitä, mikä itse asiassa on kulloinkin käytetty panos. Päättäjät ja ohjausammattilaiset itsekin ovat ehdollistuneet mieltämään ohjauksen vain resurssien kuluttajina, ei resurssien tuottajina. Yksinkertainen esimerkki ohjauksen suorasta taloudellisesta hyödystä on, että pienikin ohjauksen vaikutuksena syntyvä palkkatulojen lisäys on kansantaloudellisesti monin verroin suurempi kuin hyvään ohjaukseen tarvittava resurssien lisäys. Suomessa on hiljattain selvitetty kustannus-hyöty-analyysin avulla oppimisvaikeuksien kustannuksia ja nykyistä suurempien investointien tuomaa hyötyä yhteiskunnalle (Willberg 2002).

Ohjauspalveluiden kustannus-hyöty-analyysissa vaarana on helpoiten mitattavien asioiden painottaminen tärkeiden asioiden kustannuksella. Toisaalta resursseja eri toiminnoille ei useinkaan myönnetä pelkästään toteen näytettyjen tuloksellisuusfaktojen perusteella, vaan poliittisin perustein, so. miten tärkeäksi asia yhteiskunnassa koetaan. Poliittista päätöksentekoa ei voitane tarkastella vain rationaalisena ja lineaarisesti etenevänä prosessina. Ohjauskysymyksiin liittyvän päätöksenteon monimutkaisuutta lisää se, että ura- ja elämänsuunnittelun kysymykset yhdistävät monia poliittisia sektoreita.
Ohjauksen vaikuttavuuden kriteereitä jäsennettäessä kyse on usein näkymättömän prosessin tekemisestä näkyväksi sekä siitä miten olemassa olevista tutkimustuloksista viestitään päättäjille. Empiiristä tietoa ohjauksen tuloksellisuudesta ja vaikuttavuudesta on olemassa runsaasti (ks. Killeen 1998; Maguire \& Killeen 2003), mutta tieto on hajallaan. Haasteena on koota kotimaista ja kansainvälistä tutkimustietoa päättäjille helposti omaksuttavaan muotoon. Tarvitaan muutenkin nykyistä enemmän yhteisiä foorumeita päättäjien, tutkijoiden, hallinnon edustajien ja ohjausammattilaisten dialogiin. Suunniteltu ohjauskeskus The international centre for career development and public policy voi osaltaan tuoda tilanteeseen parannusta.

\section{LÄHTEET}

AiHe - aikuisopiskelun henkilökohtaistaminen. (2002). Opetushalllitus. http://www.oph.fi/ SubPage.asp?path $=1 ; 443 ; 9111$

Bysshe, S., Hughes, D. \& Bowes, L. (2002). The economic benefits of career guidance: a review on current evidence. Derby: University of Derby, Centre for Guidance Studies.

EU (2001). Making a European area of lifelong learning a reality. Communication from the Commission. Commission of the European Communities. Brussels 21.11. http:// europa.eu.int/eur-lex/fi/com/cnc/2001/ com2001_0678fi01.pdf

Killeen, J. (1998). The Learning and economic outcomes of guidance. In: A.G. Watts, B. Law, J. Killeen, J.M. Kidd \& R. Hawthorn (Eds.). Rehinking Careers Education and Guidance. Theory, Policy and Practice. London: Routledge.

Kurhila, A., Onnismaa, J., Piikkilä, H., Sinisalo, P. \& Vuorinen, R. (2002). Career development in Finland. In: L. Bezanson, \& E. O'Reilly (Eds.). Making Waves, Vol. 2. Connecting career development with public policy. Ottawa: Canadian Career Development Foundation.

Laukkanen, R. \& Ollikainen, A. (2001). Kansainvälinen yhteistyö koulutuspolitiikassa. Teoksessa R. Mäkinen \& O. Poropudas. (toim.). Irtiotto 90-luvun koulutuspolitiikasta. Koulutuspoliittinen artikkelikokoelma. Turun yliopiston kasvatustieteiden tiedekunnan 
julkaisuja B:67. Turku: Painosalama.

Maguire, M. \& Killeen, J. (2003). Outcomes from career information and guidance services. A paper prepared for an OECD review of policies for information, guidance and counselling services. Commissioned jointly by the European Commission and the OECD. http://www.oecd.org/pdf/M00039000/ M00039050.pdf

Mayston, D. (2002). Assessing the benefits of career guidance. Derby: University of Derby, Centre for Guidance Studies.

McCarthy, J. (2002). Ohjauksen toimintapolitiikan kehittyminen Euroopan unionissa. Teoksessa R. Vuorinen \& H. Kasurinen (toim.). Ohjaus Suomessa 2002. Jyväskylä: Koulutuksen tutkimuslaitos.

Moitus, S., Huttu, K., Isohanni, E., Lerkkanen, J., Mielityinen, I., Talvi, U., Uusi-Rauva, E. \& Vuorinen, R. (2001). Opintojen ohjauksen arviointi korkeakouluissa. Korkeakoulujen arviointineuvoston julkaisuja 13:01. Helsinki: Edita.

Numminen, U., Jankko, T., Lyra-Katz, A., Nyholm, N., Siniharju, M. \& Svedlin, R. (2002). Opinto-ohjauksen tila 2002. Opinto-ohjauksen arviointi perusopetuksessa, lukiossa ja ammatillisessa koulutuksessa. Arviointi 8:02. Helsinki: Opetushallitus.

OECD (2002). Career guidance policy review. http://www.oecd.org/oecd/pages/home/ displaygeneral/0,3380,EN-document-602-5no-27-22633-0,FF.html

OECD (2003). Country and thematic policy reviews in education. Thematic review on adult learning. http://www.oecd.org/EN/ links_abstract/0,EN-links_abstract-602-5no-no-1240-0,00.html

Onnismaa, J. (2002). Mikro- ja makrotarinat ohjauksen merkityksestä: kohti ohjauksen arviointikulttuuria. Kasvatus 33(3): 226-236.

Onnismaa, J. (2003). Personal study program as a tool for career planning and personalization of adult learning. Journal of Employment Counseling 40(1): 33-42.

Uusikylä, P. (1999). Politiikan ja talouden hallinnointi. Teoksessa Eräsaari, R., Lindqvist, T., Mäntysaari, M. \& Rajavaara, M. (toim.). Arviointi ja asiantuntijuus. Helsinki: Gaudeamus.
Watts, A. (1997). The changing concept of career: Implications for career counseling. ERIC Clearinghouse on Counseling and Student Services, Greensboro, NC. http:// icdl.uncg.edu/ft/051199-06.html

Willberg, N. (2002). Erityiset oppimisvaikeudet ja niistä seuraava syrjäytyminen kustannushyötyanalyyttisessa tarkastelussa. Laskentatoimen pro gradu -tutkielma. Jyväskylän yliopisto, taloustieteiden tiedekunta. http:// nmi.jyu.fi/doc/Nils_Willberg_-_pro_gradu_tutkielma.pdf

Young, R. \& Collin, A. (2000). Framing the future of career. In: A. Collin \& R. Young (Eds.). The Future of Career. Cambridge: Cambridge University Press. 